\title{
THE ISSUE OF SELF-DEFENCE BASED ON CRISIS MANAGEMENT AND COMBAT SYSTEM KRAV MAGA
}

The goal of this publication is to confirm that the pattern of operation, developed based on the Krav Maga combat system and crisis management, provides an individual with safety against the threat of a street attack. This pattern will be developed based on the principles of the Israeli combat system known as Krav Maga, with simultaneous consideration of four phases of crisis management. The use of crisis management stages in the improvement of the Krav Maga combat system in the face of the threat of a street attack significantly affects the individual's safety the moment this threat occurs. Later in the publication, arguments supporting the thesis will be presented in detail and the following research questions will be answered: What is the best source through which you can learn effective self-defence? How should an individual behave in particular phases of crisis management against the threat of a street attack to ensure its own safety? The article has been divided into four parts: In the first one, general characteristics of the issue of self-defence were given. The second part indicates which source is the most appropriate for learning self-defence techniques. In the next part, the characteristics of crisis management and its four phases were made, while in the last part, each of the crisis management phases was prepared in detail, the subject of which was the threat of a street attack.

\section{SELF-DEFENCE PROBLEMATICS}

Self-defence concerns every entity, such as a state or an organization, and all the threats that put those entities at risk. It involves self-defence of a given entity and other entities, values, and goods that are of special importance to them. This issue also applies to each of us. This issue of self-defence will include man as an individual, and the threats that will be discussed in the context of the possibility of effective self-defence are the so-called street attacks. A street attack should be understood as a direct, unlawful attack on any good protected by law or an attack that in any way violates the security of the attacked person. This phenomenon has existed since the beginning of human existence because man has always had to face unexpected threats. Man did not always have people or means that would protect him. Man had to deal alone with such problems. Nowadays, when problems such as cultural diversity, influx of immigrants, etc. are on the rise, the problem of self-defence is more serious than ever. We can be attacked in the least ex- 
pected moment and for reasons we do not understand. Thus, it is necessary to understand the system, techniques and appropriate patterns of operation to minimize the possibility of occurrence or the harmfulness of a given threat. This article will discuss the issue of self-defence based on crisis management. It will be shown how to ensure personal security based on four phases of crisis management. The methods on the basis of which the personnel safety system will be developed based on crisis management phases will come from the Israeli hand-to-hand combat system known as Krav Maga.

"Personnel safety is the limitation of negative experiences of an individual, resulting from its participation in social life, which manifest in the form of fear or anxiety. These are emotional states that are experienced on a daily basis, and which cannot be avoided. They differ from each other in the fact that stress concerns social risks (job loss, exam, relationship breakdown, etc.). Fear, on the other hand, is appropriate for situations of physical danger (getting beaten up by accidentally encountered thugs, possibility of suffering injuries as a result of an accident, etc.)" (Kołodziejczyk, 2010: 97-98). A street attack falls into the category of threats that are the cause of the fear described above (the situation of physical danger), which is one of two elements threatening personal safety. Every person, regardless of place of residence, feels a different degree of fear of a street attack. It is a global, timeless and universal problem - it affects units on every continent at the same time and generates serious human losses. Those threatened by street attacks are not only citizens of countries famous for crime levels, such as Mexico or Colombia, but also citizens of highly developed countries in which citizens feel safe. According to Eurostat's research, violent crimes, namely robbery (theft with the use of force or the threat of its use) and sexual crimes (rape and sexual assault) are a significant problem in all European Union countries (Eurostat, 2015).

A street attack can take many forms. It can be beating, rape, robbery or kidnapping. Each of these forms has many common features. First of all, it is impossible to predict all places where such an attack can occur. It is possible that such a threat will appear in the least expected places, in those where the sense of security is high. The main characteristic of a street attack, creating its subsequent elements, is the lack of rules. The fighting parties will fight maximally aggressively, not following any rules, and will do everything to survive and win, which is often associated with the opponent being eliminated. In street combat, there is a very high probability that the fighting parties will not have the health and lives of their opponents in mind. A street attack may result in the murder of a defending person, this fact causes a huge fear of this threat, because murder is the strongest threat to the sense of security (Hołyst, 2014: 21). The fact that there are no rules results in further elements that pose a significant challenge to personal safety. These are situations such as the occurrence of an armed aggressor or many aggressors.

\section{SOURCES THAT ALLOW GAINING SELF-DEFENCE SKILLS}

There are many methods and ways of action aimed at increasing personal safety. In the first place, they should prevent a street attack, then allow us to survive it if one occurs. According to the most popular, most instinctive method, avoid dangerous places where 
you can be attacked, but it is not possible to determine all such places. Therefore, based only on the method of avoiding dangerous places, the subject will not ensure personal safety. Another method is to have tools, weapons that will increase the combat value of the subject and help to overcome a potential aggressor, but without proper skills, training, this method may also be ineffective. Without proper weapons skills, there is a high risk that the aggressor will be able to take away the weapon and use it against the defender. An appropriate way to increase the personal safety of an individual is to have combat skills and knowledge of the rules to prevent a street attack, and to behave appropriately when one occurs. There are three basic sources, thanks to which it is possible to acquire fighting skills and learn the rules prevailing in the melee combat environment. These basic sources are: martial arts, combat sports and combat systems.

Martial arts are characterized by a long history and an emphasis on tradition. Examples of martial arts are karate or judo. Practices take place according to a standardized pattern, taking into account the smallest details related to the movement of the exerciser (for the technique to be considered correct, even the smallest details of the movement must be maintained). The element of respect for the opponent plays an important role here. Before, as well as after doing any fighting technique in accordance with the rules of teaching, a bow should be done to pay respect to your opponent, or rather to your partner in practice. It is forbidden to make dishonourable moves not included in the rules of the given martial art. Each play has strictly defined rules that characterize its style and way of fight. Demonstrations and martial arts techniques must meet all specific rules in order for their performance to be considered correct. Effectiveness, combat value in real combat are not that important, but the correctness of techniques in the aesthetic sense consistent with the traditional pattern constructed by the long history of a given art is what matters.

Combat sports are aimed at preparing a given competitor to fight effectively in a controlled environment with specific rules. The controlled environment should be understood as an environment in which there is control of applicable rules and enforcement of their observance. When during a sports fight, one of the players breaks one of the rules on the basis of which the fight takes place, the fight will be interrupted by third parties. For this source, thanks to which you can learn to fight, there is also a characteristic phenomenon, which is tunnel vision. In combat sports, the combatant has only one opponent. The focus is entirely on this opponent. The combatant does not observe the surroundings, and is not ready for an attack from another side (because in combat sports such an attack is impossible). Just like in a tunnel, the combatant looks only straight, all the time focusing on one opponent (hence the term "tunnel vision"). Examples of combat sports are boxing or wrestling.

Sports and martial arts are not the most appropriate in the context of self-defence, because they do not take into account many factors that can occur in real combat. Such factors include the possibility of many aggressors, an armed aggressor, unfavourable surroundings.

The third source where we can acquire fighting skills is combat systems. They are $100 \%$ focused on effectiveness. Combat training systems are designed to prepare the student to fight in the real environment and as much as possible increase the probability of survival of a street attack. They take into account all factors that may occur in real 
combat. There are no rules, the priority is effective defence, fighting off the aggressor, which often involves the lack of care for the health and life of the opponent. Most combat systems come from battle systems that were originally used by uniformed services such as the military and the police. Their military character affects effectiveness during a real battle against an opponent (i.e. one in which no rules apply, and parties fighting at all costs want to win, the so-called "fight for life and death"). What is more, great attention is paid to the knowledge of behaviour rules to prevent the occurrence of a threat and how to behave in an emergency situation when there is no direct attack.

Scheme 1. Table of characteristics for individual sources allowing to acquire combat skills

\begin{tabular}{||l|l|l||}
\hline \multicolumn{1}{|c|}{ Martial arts } & \multicolumn{1}{c|}{ Combat sports } & \multicolumn{1}{c|}{ Fighting systems } \\
\hline- Respect for the opponent & - Effectiveness & - Effectiveness \\
- Emphasis on history and traditions & - Controlled fight & - Real fight \\
- Aesthetics, attention to detail & - Tunnel vision & - Safety of the defender is priority \\
- Rules & - Rules & - No rules \\
\hline
\end{tabular}

Source: Own study.

An example of a combat system is the Israeli combat system known as Krav Maga (עebr. עגמ ברק). Krav from Hebrew means fight, while Maga means close. Krav Maga should be directly translated as close combat. The creator of this system is Imi Lichtenfeld who has Jewish roots. In 1948, when the State of Israel was established, Krav Maga was permanently introduced into the uniformed services training program. The system appeared in Poland in 1995, for the first five years it was available only to uniformed services, and in 2000 the first Krav Maga schools for civilians were established in Poland. The system consists of three sectors: military, for security services and for civilians.

In the military sector of Krav Maga, most techniques end up with the aggressor being neutralized. The defender's priority is to defeat the aggressor, it is desirable that the execution of the technique would cause a permanent injury to the health or death of the attacker. It includes very brutal techniques adapted to the environment of the battlefield. A great emphasis is also placed on the ability to fight with firearms and melee weapons. This system was created for military formations, individual groups of techniques can be assigned to tactics - green (action in forest, desert, etc.), black (urbanized area), red (battlefield medicine) and grey (vip protection).

The Krav Maga sector for security services was created for such groups as, for example, the police and security formations. Techniques coming from this sector are aimed at overpowering the aggressor, taking control over him without doing excessive harm. The sector has techniques whose implementation will be in accordance with the law applicable in a given country. For the need of each state, a base of techniques for security services should be individually constructed, because in each of them there is a different law, which means the services have a different scope of action, another tolerance for the use of force. For example, in Israel, Krav Maga for police forces contains much more brutal techniques than Krav Maga for law enforcement in Poland. In the sector, a lot of attention is also paid to aspects such as the ability to use means of direct coercion (handcuffs) and the ability to use firearms, as well as teamwork. 
Considering the issue of self-defence, concerning each person as an individual, special attention must be paid to the third of the sectors of the discussed Israeli handto-hand combat system - Krav Maga for civilians. The techniques in this sector are constructed in a way to be effective when applied by every person, regardless of age, gender and physical conditions. The techniques are not based on strength, but on attacks on sensitive points, such as the crotch, eyes. These are points on the human body that cause great pain when hit. The pain is usually strong enough to exclude the attacker from further confrontation. It should be remembered that Krav Maga techniques can affect the health and life of the aggressor. They are intended to ensure the safety of the defending person, but they do not have the health and life of the attacker in mind (the use of most of the Krav Maga techniques involves exceeding the boundaries of the necessary defence).

Krav Maga for civilians is guided by three main principles: avoid, run, fight. According to the first rule of Krav Maga, dangerous places, places where a threat may occur should be avoided. To reduce the probability of an attack, avoid places where potential aggressors may appear. Due to the fact that it is impossible to recognize all dangerous places, observing the first rule of Krav Maga, a given subject is exposed to the risk of falling victim to a street attack. This situation is anticipated by the second and the third of the rules of Krav Maga. According to the second rule, when we find ourselves in a dangerous place, you should escape from it as soon as possible. In many situations, escape may not be possible. In buildings such as a lift, an enclosed room or a moving vehicle, an escape will be impossible. In this situation, refer to the third Krav Maga rule. Fight aggressively, and the fight must be effective, without any restrictions and with the use of all objects that are around and that can be used as a weapon in battle. Fighting in such a way will increase the probability of survival, ensures security for the defender.

\section{FOUR PHASES OF CRISIS MANAGEMENT}

To develop an effective pattern containing methods, techniques and ways of action for the personnel security policy, a model is needed, a system tested in practice, on the basis of which it will be possible to construct a security policy against the threat of a street attack. The broadly understood crisis management can serve this purpose. According to the Act on Crisis Management, Art. 2, crisis management is "the activity of public administration bodies being an element of national security management, which consists in preventing crisis situations, preparing to take control over them through planned actions, reacting in case of crisis situations, removing their consequences and reconstruction of resources and critical infrastructure." In the definition cited in the act, crisis management is presented as an activity consisting of four phases: prevention, preparation, reaction, reconstruction. It is a scheme that allows public authorities to effectively counter the threats against national security. It should be noted that it is a continuous process, consisting of interrelated stages (Grocki, 2012: 41).

The first phase is prevention that consists in reducing the probability of occurrence of a given threat and gathering as much information about potential threats as possible. It is characterized by all preventive actions aimed at reducing the possibility of crisis 
and analytical situations, the purpose of which is to best understand the specifics of potential threats and develop methods that will allow for an effective prevention, and in the next phase, preparation for the occurrence of a crisis situation. According to the crisis management Act, Art. 3, a crisis situation should be understood as a situation "adversely affecting the level of security of people, property in large sizes or the environment, causing significant restrictions in the operation of competent public administration bodies due to the inadequacy of forces and resources."

The second phase of crisis management: preparation. In order for the activities in this phase to be effective, a sufficient amount of information from the previous phase is necessary. Without the information, it is not possible to properly prepare the actions to be taken when the crisis situation occurs. The preparation phase consists in preparing the entities responsible for reacting in the event of a crisis situation. It is also necessary to specify the necessary forces and means to carry out activities during and after the occurrence of a threat (Marciniak, Molek, Stec, 2011: 56). Actions taken in this phase include training, developing action plans.

The next phase of crisis management is reaction. It is the most visible and the easiest to recognize of all four phases (Grocki, 2012: 43). It covers activities from the moment a threat occurs, until the crisis situation is overcome and security is provided to the entities affected by the threat. It covers all activities of a given subject during a crisis situation. It consists in launching activities, procedures created in the previous phase.

The last phase of crisis management is reconstruction. It involves the reconstruction of resources, removing the effects of a given threat. It ends when a given entity that had fallen victim to a threat returns to the state from before the crisis or to a better one (Piwowarski, Rozwadowski, 2016: 350). This phase should be divided into short-term and long-term. Short-term reconstruction includes activities immediately after the end of the reaction phase and consists in providing elements necessary for the functioning of subjects. It is based on providing the minimum means to survive. It is characterized by the intensity of activities and a short period. Long-term reconstruction begins when there is no immediate threat to the life and health of the entities concerned. It consists in reconstructing the state that was before or a better one. It is characterized by a low intensity of activities and a longer period.

Acting in accordance with the four phases of crisis management allows, if possible, preventing the occurrence of a given threat, gathering the necessary information about it, and then preparing for its occurrence in a careful manner. Once it occurs, it allows reacting to it in an effective way, so as to reduce the effects of its occurrence, then rebuild lost goods and values. These phases form a scheme that indicates how to maintain the state of security, prepare for the occurrence of danger and in an emergency situation fight for safety, emphasizes the need to rebuild losses after the occurrence of a threat. It should be noted that these phases are an open pattern, which means that after the fourth, last phase of operation they are not completed. The conclusions from the previous phases are learnt and the transition to the first phase takes place. The pattern of action that was originally created for public administration bodies can be applied by any entity to any type of threat. It can be used not only by countries to manage national security, but also by any other subjects. For example, the crisis management scheme 
can be used by business companies to develop their own security policy (Grocki, 2012: 14). The four phases of crisis management can also be used when considering the issue of self-defence to develop a pattern of actions aimed at improving personal safety.

Scheme 2. Four phases of crisis management

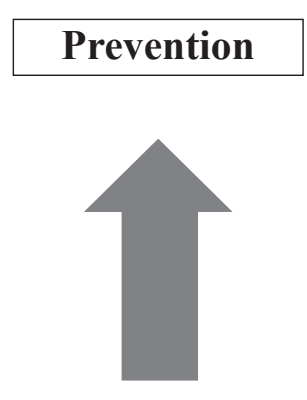

Reconstruction
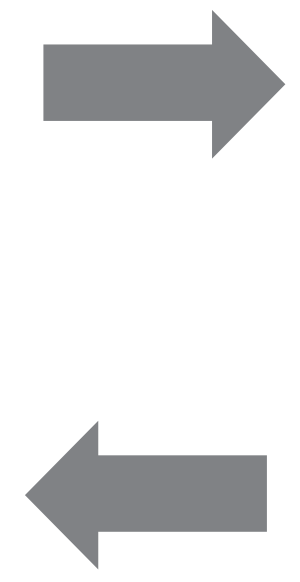

Preparation

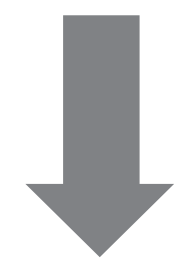

Reaction

Source: Own study.

\section{THE ISSUE OF SELF-DEFENCE ON THE BASIS OF FOUR PHASES OF CRISIS MANAGEMENT}

The next part of the publication will cover the issue of self-defence based on four phases of crisis management. The methods and ways of action will be taken from the Krav Maga combat system. It should be remembered that the operation in accordance with the presented pattern is aimed at improving personal safety, and in particular survival of an attack on the street. The use of the indicated guidelines may be tantamount to crossing the boundaries of the necessary defence and the related legal consequences.

\section{Prevention}

According to the first rule of Krav Maga, dangerous places, places where a threat may occur should be avoided. You need to research a specific environment to know what places are dangerous. To prevent an attack, you must also look like a self-confident person who is not afraid of a potential attack. Aggressors look for victims, people who look like non-resistive people, submissive people. Moving on a daily basis you should walk straight, look ahead, you cannot look like a victim because it can increase the probability of attracting an attack. Also, do not make excessive eye contact with potential aggressors, because it can arouse an offensive attitude and aggression. As part of this phase, you should also determine what types of attacks can occur and pre-match appropriate response methods and combat techniques. It should also be determined what kind of attacks will be directed to particular training groups. For example, males 
are most often attacked by punching, while females by various types of strangulation, hand-shakes, and kidnapping attempts. Each group should practice defending against each type of attack but thanks to such an analysis, it is possible to devote special attention to defence techniques appropriate to attacks that will most likely occur.

It is impossible to predict all possible scenarios that may occur during a street attack. There is a high risk that in a real combat situation even people with many years of experience in combat systems will be surprised by a scenario because they did not practice it in training rooms. To increase the chances of instinctive, fast and effective defence, it is necessary to develop as many scenarios as possible in a given environment and choose techniques that will best match a given situation and ensure safety to the defender. To work out as many scenarios as possible, you should take into account all elements whose occurrence is highly probable in a street attack situation. These are such elements as an armed aggressor, several aggressors, unfavourable surroundings.

\section{Preparation}

Having information about the nature of the fighting environment and a set of possible attack scenarios, it is time for the second phase - preparation. In this phase, all techniques should be practised, including all elements that may occur in real combat. During training, exclude techniques that will prove ineffective in conditions close to real ones (the training should reproduce the conditions prevailing in a real fight such as stress but it is impossible to reproduce them fully).

In many cases, during martial system training, it is forgotten that in a self-defence situation, the defender will not be dressed in comfortable clothes allowing free performance of a given technique. It should be remembered that every day, most people wear clothes that differ than the ones they have during practices. Those pieces of clothing are tight trousers that prevent the execution of certain techniques (for example, making a high kick, Krav Maga avoids kicks higher than the level of the aggressor's crotch, because they cannot be made due to tight pants and pose a risk of loss of balance when on wet or uneven surface).

Another element that should be taken into account during training is the possibility of an aggressor armed with melee and firearms. According to the PWN Polish language dictionary, melee weapons are "hand combat weapons." Tools such as a knife and a stick should be especially taken into account. These are the two most common melee weapons used on the street, some of the rules for defending against these tools are very different. Hoever, there are also common rules:

- first, you must escape, because the fight with an armed aggressor is very risky (second rule of Krav Maga);

- when an escape is not possible, use items that are nearby to increase your combat value and increase the chances of survival. If you decide to fight, do so as aggressively as possible, without any restrictions (according to the third Krav Maga rule).

Fighting a person with a knife is very dangerous. There is no effective defence against the aggressor armed with a knife but through training it is possible to increase 
the probability of survival. Performing an effective defence against such an aggressor is difficult due to the fact that a technique appropriate to the aggressor's attack should be performed. It is very difficult to determine how the aggressor will attack in a short period and choose an appropriate type of defence to it. If an improper type of defence against a given attack is chosen, the defence is ineffective, which is associated with a high probability of injuries. The tactic of fighting a knifer in the open space is based on keeping the right distance, blocking, moving off the attacking arm and making kicks on the crotch to stop the aggressor's attack. If fighting in an area with limited space, when it is impossible to hold a distance, you should take control of the hand with the knife (in practice, such techniques are very difficult to perform).

Fighting an aggressor armed with a stick in most cases is based on the principle of shortening the distance, taking control over the hand armed with the stick and making strikes that are intended to prevent the aggressor from continuing the fight. Performing effective defence is simpler than in the case of a knifer, because it is easier to predict how the aggressor with the stick will attack and in most cases the use of one technique is effective against most types of attacks (high probability of effective defence).

According to the Law on Weapons and Ammunition, "firearms are any portable barrel weapons that throw out fire or are intended to throw out fire, or can be adapted to throw out one or more bullets or substances as a result of a propellant." According to police statistics, in 2018 in Poland as many as 768 crimes were committed using firearms (Offenses, 2018). This is a real threat that may accompany a street attack. If there is a long distance between the defender and the aggressor armed with firearms, it is not advisable to shorten the distance to disarm the aggressor, because the defender will make it easier for the aggressor to take a good shot. In this situation, the right solution is to make an escape. When escaping, run as fast as possible and change the direction of the run at a high frequency to make it more difficult for the aggressor to fire accurately. The purpose of the escape is to find a safe place and shelter. If there is a short distance between the defender and the aggressor, it is possible to perform Krav Maga techniques and effectively disarm the aggressor.

Several aggressors often appear in a street attack. This is another element that should be taken into account while training. Performing a technique involving the fight with one aggressor, stay alert, constantly observe the surroundings and be ready for subsequent aggressors appearing. Krav Maga techniques predict the fight with several aggressors, it is a very dangerous fight and hard to survive in practice. First you have to try to escape, if impossible, you have to fight in accordance with the third rule of Krav Maga.

During the preparation phase, training sessions should be carried out not only in the training room, but also in conditions similar to those occurring in real combat. It is necessary to organize training session in tight spaces, means of public transport, because the fight in such an environment is different from the fight in the training room, where there are elements such as open space and soft surface (training mats). Techniques that are effective in the training room may not be effective in other places where there are other conditions. Therefore, it is necessary to choose techniques and tactics of fighting appropriate to a specific environment. For example, fighting in closed spaces, such as a lift, take a different combat tactic than in open spaces. In a closed room, from which 
there is no escape, end the fight by controlling the aggressor, and not escaping as in the case of fighting in the open area.

\section{Reaction}

The reaction phase includes situations in which a given threat occurs. When an attack occurs, if possible, you must escape, the fight is the last resort. There is tremendous stress during a real fight. It can take on two forms: positive or negative. Positive stress will drive you to act, it will cause great anger, adrenaline, aggression, resistance to pain and the will to fight. Negative stress will result in a passive attitude, fear and lack of action, lack of any defence and counterattack. At Krav Maga training sessions, students are taught an appropriate response to attack and stress management. They learn how to stimulate positive stress, thanks to which they take a fight in accordance with the third Krav Maga principle. They fight maximally aggressively, they do not set any limits. An element to keep in mind when fighting in any type of scenario is to use all possible items to fight, which can increase the defender's value. To react properly in the reaction phase, it is necessary to correctly perform two elements: use an appropriate technique and have the right reaction time. In a situation of performing the right technique but too late, the defending person will not be able to fight off the attack. These are two key conditions to perform an effective defensive technique.

A verbal form of attack may be used to stop the aggressor as well. Shouts are recommended during the fight. Showing aggression through verbal signals in an effective way can scare, discourage the aggressor from continuing the attack.

\section{Reconstruction}

After the end of the confrontation with the aggressor, escape or control and calling for help, the reconstruction phase takes place. This phase includes activities aimed at reconstructing physical and psychological injuries taken during the attack and drawing lessons from the reaction phase and improving techniques or creating new ones if the used ones proved ineffective.

An important element in the context of self-defence in the reconstruction phase is drawing conclusions from the confrontation (reaction stage) and the events that had led to it. One should analyse previous actions, work on new scenarios, if the threat caused surprise, confusion. The reconstruction phase does not only involve analysing the situation that concerned a given unit or units from its environment. The subject of the analysis may be situations that do not apply to a given subject. For example, during the reconstruction phase, analyses of street fighting on monitoring, interviews or reports with people who are victims of a street attack may be helpful.

During confrontation there is huge stress, aggression, tantrum. Regardless of the level of advancement in fighting skills, this is an element that accompanies almost everyone in a street fight. After such a confrontation, there is a high probability of having psychological injuries such as remorse, fear, disorientation and, above all, post- 
traumatic stress. This stress can cause deep and permanent changes in psychological and physiological functioning, it is caused by situations of life threatening or physical integrity, during which a person experiences intense fear, a sense of helplessness or terror - these are elements accompanying a street attack (Hołyst, 2014: 289). The reconstruction phase includes activities aimed at improving the mental state of the person participating in the fight.

There is a high risk of a physical injury during street fighting. These can be lifethreatening wounds, such as injuries sustained as a result of fighting a knifer. Advanced techniques that allow working properly to provide yourself or others with safety in a situation when wounds can occur are present in red tactics (the military sector of Krav Maga). Such activities are in the reconstruction phase.

\section{$* * *$}

Summing up, most of today's countries and entities have their own crisis management system based on four phases of crisis management. This is proof that the crisis management phases are the right tool to develop a security system against many threats, regardless of which subject they concern: the state, an organization or an individual. When dealing with the issue of self-defence, many attack scenarios have to be taken into account. Their diversity is influenced by many factors that change the specificity of the attack. Crisis management phases are the right tool to develop appropriate patterns of action, reduce the likelihood of an attack, prepare for its occurrence, react effectively when the attack occurs, and take correct actions to recover injuries and draw conclusions and apply changes to the techniques used so that in the event of a similar threat in the future the level of safety increases. The methods used in the publication, the action patterns come from the Krav Maga system, and are designed to ensure security at all costs and repulse the aggressor's attack. Safety of the defender is priority. They do not take the health and life of the aggressor into account, which causes a lot of controversy. The techniques contained in it in many cases exceed the boundaries of the necessary defence, which means that after applying them one must deal with legal consequences. Proceeding in accordance with the pattern presented in the publication will not provide full personal security, because the threat of a street attack is very complex, but it will significantly increase the individual's personal safety. Thanks to the use of knowledge derived from the Krav Maga combat system and its development in accordance with the four phases of crisis management, following the constantly changing environment, it is possible to create an effective security system against the threat of a street attack.

\section{REFERENCES}

Abramczyk A., Ciczkowski W. (1999), Bezpieczeństwo człowieka w środowisku lokalnym, Olsztyn. Chojnowski L. (2018), Bezpieczeństwo człowieka i społeczeństw w procesie dziejowym, Słupsk.

Cendrowski J. (1973), Psychologia walki i dowodzenia, Warszawa.

Dobrzyjałowski J. (1994), Samoobrona i techniki interwencyjne policji, Legionowo. 
Drabik K. (2013), Bezpieczeństwo personalne i strukturalne, Warszawa.

Grocki R. (2012), Zarzadzanie kryzysowe: dobre praktyki, Warszawa.

Grabińska T., Spustek H. (2013), Bezpieczeństwo personalne a bezpieczeństwo strukturalne państwa: wolność i bezpieczeństwo obywatela, Wrocław.

Hołyst B. (2014), Bezpieczeństwo: ogólne problemy badawcze, Warszawa.

Hołyst B. (2006), Psychologia kryminalistyczna, Warszawa.

Hołyst B. (2014), Bezpieczeństwo jednostki, Warszawa.

http://statystyka.policja.pl/st/wybrane-statystyki/bron/bronprzestepstwa/50844, Przestepstwa-przyuzyciu-broni.html (26.03.2019).

https://ec.europa.eu/eurostat/statistics-explained/index.php?title=Archive:Crime_statistics/ pl\&oldid $=257905(26.03 .2019)$

http://kravtrening.pl/about/historia-krav-maga/ (23.03.2019)

Jabkowski P. (2006), Przestepczość a poczucie bezpieczeństwa wśród mieszkańców Poznania: analiza socjologiczna, Poznań.

Kucharski M. (2012), Bezpieczeństwo - dyscyplina w obszarze nauk społecznych, Łódź.

Kołodziejczyk K. (2010), Personalny wymiar bezpieczeństwa, Częstochowa.

Mcnab C. (2017), 501 sposobów samoobrony bez użycia broni, Czerwonak.

Marciniak R., Molek W., Stec K. (2011), Zarządzanie kryzysowe w systemie kierowania bezpieczeństwem narodowym, Warszawa.

Piwowarski J., Rozwadowski M. (2016), System zarządzania kryzysowego jako element bezpieczeństwa narodowego, Kraków.

Polcikiewicz Z. (2012), Teoria bezpieczeństwa, Wrocław.

The Act of 21 May 1999 on weapons and ammunition, Journal of Laws of 1999, No. 53, item 549, http://prawo.sejm.gov.pl/isap.nsf/download.xsp/WDU19990530549/U/D19990549 Lj.pdf (25/03/2019).

The Act of 26 April 2007 on crisis management, Journal of Laws of 2007, No. 89, item 590, http://prawo.sejm.gov.pl/isap.nsf/download.xsp/WDU20070890590/U/D20070590Lj.pdf (25/03/2019).

PWN Polish Dictionary (2015), Wydawnictwo Naukowe PWN, Warsaw.

Wróblewski R. (2013), Zarządzanie kryzysowe jako element zarządzania bezpieczeństwem narodowym, Siedlce.

\begin{abstract}
The goal of this publication is to confirm that the pattern of operation, developed based on the Krav Maga combat system and crisis management, provides an individual with safety against the threat of a street attack. At the beginning of the article, the issues of self-defence were discussed, the Krav Maga combat system was presented and the most important elements of the crisis management theory were introduced. Later in the paper, an analysis of each of the crisis management phases was carried out in relation to the risk of a street attack. The author answers the research questions in detail: What is the best source through which you can learn effective self-defence? How should an individual behave in particular phases of crisis management against the threat of a street attack to ensure its own safety? The analysis made in the paperwork based on available sources, observations and the author's experience gained gives an unambiguous confirmation that combat systems are the best source through which one can learn
\end{abstract}


effective self-defence, because they take into account all the elements that accompany a street attack. Following the scheme included in the publication, every person, regardless of age, sex or physical posture can effectively increase their own personal safety.

Keywords: personal safety, human security, self-defence, Krav Maga, crisis management, crisis management cycle

\section{PROBLEMATYKA SAMOOBRONY W OPARCIU O ZARZĄDZANIE KRYZYSOWE I SYSTEM WALKI KRAV MAGA}

\section{STRESZCZENIE}

Celem niniejszej publikacji jest potwierdzenie, że schemat działania, opracowany w oparciu o system walki Krav Maga i zarządzanie kryzysowe zapewnia bezpieczeństwo jednostce wobec zagrożenia, jakim jest atak uliczny. Na początku artykułu omówiono problematykę samoobrony, przedstawiono system walki Krav Maga oraz wprowadzono najważniejsze elementy teorii zarządzania kryzysowego. W dalszej części dokonana została analiza każdej z faz zarządzania kryzysowego, w odniesieniu do zagrożenia atakiem ulicznym. Autor szczegółowo odpowiada na pytania badawcze: Jakie jest najlepsze źródło, dzięki któremu można nauczyć się skutecznej samoobrony? Jak powinna zachować się jednostka w poszczególnych fazach zarządzania kryzysowego wobec zagrożenia atakiem ulicznym, aby zapewnić sobie bezpieczeństwo? Przeprowadzona w pracy analiza w oparciu o dostępne źródła, obserwacje oraz zdobyte doświadczenia autora daje jednoznaczne potwierdzenie, że systemy walki są najlepszym źródłem, dzięki któremu można nauczyć się skutecznej samoobrony, ponieważ biorą pod uwagę wszystkie elementy, które towarzyszą atakowi ulicznemu. Postępując zgodnie ze schematem zawartym w publikacji, każda osoba, bez względu na wiek, płeć czy posturę fizyczną może efektywnie zwiększyć własne bezpieczeństwo personalne.

Słowa kluczowe: bezpieczeństwo personalne, bezpieczeństwo ludzkie, samoobrona, Krav Mag, zarządzanie kryzysowe, fazy zarządzania kryzysowego 
